UDC 316.334 .4

DOI $10.21564 / 2075-7190.43 .187913$

Pohribna Viktoriia Leonidivna, Doctor of Sociology, Professor,

Professor of the Department of Sociology and Political Science,

Yaroslav Mudryi National Law University, Kharkiv, Ukraine

ORCID: 0000-0002-5101-0386

e-mail: vilpog2017@gmail.com

Sakhan Olena Mykolaivna, $\mathrm{PhD}$ in Sociology, Associate Professor, Associate Professor of the Department of Sociology and Political Science,

Yaroslav Mudryi National Law University, Kharkiv, Ukraine

ORCID: 0000-0002-3212-031X

e-mail: supersahan2013@gmail.com

\title{
PROBLEM OF «LANGUAGE OF SOCIOLOGY» USAGE IN LEGAL THEORY AND PRACTICE
}

The article examines the feasibility and the possibility of "the language of sociology" usage in jurisprudence. It is proved that "the language of sociology" not only promotes the implementation of the methodological function of law, but actively supports «the spirit of law" in the studying of social processes. It is emphasized that the coexistence in the modern society of two systems of norms - social legal and social non-legal-requires the search for differentiation criteria. As such criteria, it is proposed to use the criterion of coercion and the criterion of the consideration procedure.

Key words: language of sociology, categories of sociology in law, sociology of law, social legal norms, social non-legal norms.

Problem setting. The modern development of the system of socio-humanities is characterized by the organic interweaving of their object-subject field, categorical apparatus and methodology and research methods. In this sense, sociology often acts as a «translater». This role is most fully realized in the creation, functioning and development of interdisciplinary scientific areas, among which a special place belongs to the one that emerged at the junction of sociology and jurisprudence and has a two-direction orientation - legal sociology and sociology of law.

Today, thanks to the classical study of Jean Carbonnier [1], legal sociology is considered a science that has a broader field of research than sociology of law, since it covers all phenomena, which in one way or another related to law, everything in respect to which law may be a cause, a consequence or reason, whereas sociology of law is limited to a sociological analysis of legal norms and institutions. And 
although we already have proved the expediency of applying a wider approach to understanding the subject of sociology of law, since there are no such consequences of law (even distant and sometimes those deforming it), the reference to which would not help its cognition [2], we do not consider it expedient to continue the discussion within the framework of this article, but we propose to focus on the peculiarities of using the language of sociology in the study of legal phenomena, in the first place, those formed around the key concept - the social norm.

Analysis of recent research and publications. Traditionally, the problem of normative regulation of social relations is considered by lawyers within the general theory of law or the theory of sources of law. This explains the relatively large number of research (first of all, foreign) into functions of law, knowledge of law, perception by citizens about the administration of justice, etc. Especially we should highlight here the works of the European and American researchers T. Arnold [3], A. Giddens [4], G. Gurvitch [5], E. Ehrlich [6], J. Carbonnier [1], B. Cardozo [7-9], R. Pound [10,11], S. Warren and L. Brandeis [12], J. Frank [13], O. Holmes [14]. The treasury of scientific developments of the problems studied can be supplemented by the works of the representatives of the «Scandinavian» school of sociology of law (A. Hegerstrem, V. Lundstedt, S. Pass, V. Obert, H. Kleette, V. Goldschmidt, T. Eckgoff, etc.) who study the nature and specificity of a number of important aspects of legal consciousness, legal relationships and legal activity. Also it is worth noting the works of scientists belonging to the «Italian» school (A. Pagani, G. Martinotti, E. Moriondo, etc.) who study the social origin of judges, the administration of justice, analyze the public opinion about the activity and efficiency of the courts. At the same time, if the representatives of the European school focus on the outline of the subject field of this science, then the Americans "promote» the empirical approach, considering the judge's subjective judgment as the main criterion for the lawfulness of the act, and arguing that law is created by the court and is a means of achieving social functions.

This problem was not ignored by the domestic scientists as well. From the end of the nineteenth century, social-legal problems of society were investigated by L. Gumpilovich [15], B. Kistyakivskyi [16-18], M. Korkunov [19], L. Petrazhitskyi $[20,21]$ and others. Scientific searches of Ukrainian sociologists in this field at the end of the XX - the beginning of the XXI century are associated with the names of such scholars as V. Bachinin [22], O. Dzhuzha [23], N. Osipova [24], S. Savchuk [25], O. Serdyuk [26], and others. However, unfortunately, the problem of the relation of «social legal» and «social non-legal» in the works of legal sociologists remains to a certain extent the «terra incognito», which determined the purpose of this article - an analysis of the possibilities of using «the language of sociology» in legal research. 
Presenting the main material. The starting point for such an analysis can be considered the fact that both sociology of law and legal sociology, being the branches of general sociology, study legal phenomena as a kind of social phenomena. At the same time among social phenomena there are those whose legal nature is indisputable. These include the so-called primary legal phenomena, such as legality, legal/non-legal behavior, deviations, crime, criminal situation, law enforcement/law using/law-making activities, etc., which are obviously legal because they are identified with the law and create the very sphere of law, but in essence, are social, in which there is a legal element, even if this element is not expressed in its pure form, but intertwined with others. At the same time, sociology does not artificially limit its research to the primary phenomena, but also covers secondary, derivative phenomena (responsibility, control, prevention, etc.). Although in these phenomena there is also a «social» that is not directly reframed through the prism of law, the use of «the language of sociology» allows us to deepen the analysis of law-studied problems due to the consideration of their inherent moral, ethical, and cultural aspects. In this way, sociology not only determines the legal regulators of various types of social relations, but also builds the classical sociological causal relationships and fills the legal phenomena with social content.

We consider interesting in this sense, the approach proposed by the EstonianAustrian researcher I. Tammelo, who believed that legal sociology is the sociological study of lawyers, and sociology of law is the study of legal phenomena by sociologists [27]. In any case, the crossing of not only the problem field of the two sciences, but also their categorical-methodological apparatus is fixed. However, his followers, in our opinion, make not entirely appropriate conclusion that the use «the language of sociology» in law is reduced exclusively to the attempts by lawyers to illustrate dogmatic description of some of their own institutions by the actual data. This position is most clearly expressed in the series of books by E. Hirsch and M. Rehbinder «Study of Legal Factology and Sociology of Law», published in the 60-80 years of the twentieth century in Germany. Thus, the Director of the European Institute of Legal Psychology, Honorary Professor of the Yuriy Fedkovych Chernivtsi National University, Dr. Manfred Rehbinder proposed a theory in which the intersection of categorical-methodological apparatus and the problem field of jurisprudence and other social sciences is determined through the concept of three dimensions of law: in terms of values - philosophy of law, in terms of norms dogmatic jurisprudence, in terms of realities - sociology of law. The latter, in turn, is divided by him into genetic sociology, which studies the social genesis of law, and operative sociology, which studies the influence of law on social life [28, p. 64-69]. So, as we see, in this way, «the language of sociology» not only promotes the implementation of the methodological function of law, but actively supports «the spirit of law» in the study of social processes. 
In the first modern Russian textbook on sociology of law, by V. Kazimirchuk and V. Kudryavtsev, although it is argued that sociology of law is «a new legal (emphasized by us -V.P., O.S.) discipline», yet it is underlined that «sociological research in law is conducted on the verge of sociology and law...»; that there are such social phenomena, the study of which «is impossible to carry out within the framework of the legal science, which is understood as an analysis of norms, since its effectiveness is finally manifested, precisely in the impact on non-legal phenomena, on the actual relations of people»; that «the process of sociologization of jurisprudence involves the development of new problems that can not be posed within the juridical conception»; that «sociology of law is a new scientific direction in social sciences, which investigates the legal system in connection with life, social practice» $[29$, p. $2,4,7,12,14,30]$.

Continuing the study of the role of sociology in the functioning and methodological development of categorical apparatus of law, we remind that in the early twentieth century in American sociology, law was usually considered only as a component of social control. In our time, some representatives of the American sociology offer to use the distribution of general sociology to the sociology of professions, sociology of decisions and sociology of organizations, in which most aspects of the activities of the representatives of legal specialties automatically fall into the subject field of sociology of professions; lawmaking and justice - into sociology of decisions, and most of the structures of the current law - into sociology of organizations or social institutions. In our opinion, this approach is somewhat narrowed, since it is based on a simplified understanding of the specifics of law, particular flexibility, and the unique ability of «the spirit of law» to organize the activities of all formal (and even many informal) organizations. On the other hand, one can not but take into account that many concepts used by legal sociology («social coercion»), «social control», «collective consciousness»), etc.) are the notions of general sociology, with the added legal emphasis. And even some of those categories that, it would seem, express purely legal phenomena (social prevention, delinquent behavior), are introduced into the scientific circulation by sociologists. Consequently, the intersection of the categorical apparatus of sociology and law is evident.

Lawyers did not need to expect the emergence of sociology of law in order to notice that relations between people are regulated not only by law but also by other norms. At the same time, they always paid special attention to the distinguishing of law and morality. The maxima of the Roman lawyer Paul: «Not everything that is lawful, is noble» («Non omne quod licet honestum est») was positioned in «Digests» as a norm. But we, sociologists, are always insistently emphasizing that all that traditionally opposed to law under the name of morality artificially narrows the problem. In essence, the matter here is much more complicated. Law should be 
distinguished from the system that is regulated by the internal motives of a person (personal morality), and from the apparatus of external motivation that is used by the society. The latest category, which does not refer to either law or morality, is suggested by sociologists to refer to morals, distinguishing among them proper morals, or mores, and folkways. This allowed them to build a trilabic construction, which became today classical: law; mores; falkways [1, p. 155]. We propose to consider in what way this unifying law and sociology construction works, on the example of the analysis of correlation of goals and means of their achievement in the assessment of legal phenomena and their consequences. This is exactly what will enable us to clearly trace the mechanism of crossing the categories of sociology and jurisprudence.

The question of how the goals and means of achieving them relate, in the classical formulation, is as follows: does the goal justify any means of achieving it? It is known that the history of ethical thought has put forward two alternative answers to this question, which are most clearly embodied in the concepts of Machiavellianism and abstract humanism.

Naturally, in its extreme forms, the apology of Machiavellianism and abstract humanism occurs quite rarely, but law-enforcement activity, as a real embodiment of «the spirit of law» in social relations, requires an urgent scientific decision of the problem of the correlation of purpose and means of its achievement in the legal sphere, which becomes possible only with the involvement of «the language of sociology». This is largely due to the long-standing negative assessment in public opinion, not only of means, but even of the goals of law-enforcement actors, especially if they are aimed at protecting certain political forces or corporate interests.

This is confirmed by the findings of the authors of the monograph entitled «Unlawful Violence in the Bodies of Internal Affairs. Sociological and historicallegal analysis», which state that the problem of violence in the activity of lawenforcement structures is of a universal nature, regardless of the nationality of the police officers and the degree of economic development of the country. Abuse of force by the police and rude, aggressive performance of their official duties by them is a fairly common international phenomenon. According to the Commissioner for Human Rights of the Russian Federation, between 50 and 80 percent of all suspected persons have been confronted with ill-treatment and torture during the investigation [30, p. 178-179]. The data from the polls of Ukrainian citizens with the experience of detention confirm similar figures (64\% - physical violence, $84 \%-$ psychological). The attention is also drawn to the fact that almost half of the 2,000 respondents - residents of the five regions of Ukraine justify (highlighted by us $-V . P ., O . S$.) the use of unlawful violence in some cases, or in relation to certain groups and categories of detainees [30, p. 101-106]. Consequently, in a society there is a situation where people completely assume the acts or behavior that can 
be assessed as morally and socially positive, although the very purpose or means, as independent phenomena, may be to a greater or lesser extent negative. So, let's say, combating corruption is clearly a moraly and socially approved goal, while coercion for a person is unlikely to receive the same unequivocal assessment. And this, in turn, indicates that it is necessary to turn to «the language of sociology» for a full explanation of the mechanism of the correlation of goals and means in activities that relate to the use of legal norms.

The conclusion of sociologists regarding the coexistence in the modern society of the two systems of norms - social legal and social non-legal - needs to find a differentiation criterion, for example, the well-known thesis «Do not kill» can be equally perceived as a religious commandment, and as a moral imperative, and as a norm rof law.

J. Carbonnier distinguishes between two such criteria, both of which fall within the scope of application of norms. This is the criterion of coercion by which the norms are implemented, and the criterion of the order of consideration, by which the implementation of the norm may be limited to the recommendatory nature of the latter [1, p. 165].

As an important part of the sociology of E. Durkheim, coercion acquired the character of the classical criterion: if a norm was created by society in order to be used, this usage should be enforced by coercion. However, the nature of such social coercion is not always the same, it has its own specificity regarding legal and nonlegal norms. For the latter, in the notion of «social coercion», the definition of «social» is essential, since it involves only taking into account coercion initiated by society and ignoring the self-coercion of the personality (in the Kantian understanding of ethics). Social coercion in law comes from specialized bodies and performs a consciously established function. To understand how this criterion works is possible by answering the question: if society puts a certain degree of coercion in the norm, does it foresee a mechanism for enforcing this norm? With a positive answer, we are dealing with a social legal norm, with a negative one - with a social non-legal, that is the one without legal consequences. It seems as if everything is very simple and understandable. But even in the case of a positive answer there is a problem of social justice, which in principle focuses on the correspondence of the goal and means of achieving it. For example, if the court sentences a criminal offender to three years of imprisonment for a robbery, then the principle of the correspondence of the means (imprisonment, as a form of coercion) with the purpose (combating crime) is respected. But in that case if a similar remedy will be applied for a much less socially dangerous act (for example, crossing the street in an improper place), the principle of correspondence between the purpose and the means is disturbed due to the loss of balance in the system of crime-and-punishment. At the same time logically, one more question arises: «Is there no shifting from the 
goal of combating crime to the «tightening of the nuts», that already goes beyond the legal field?». Thus, careful consideration is required for the analysis of the second differentiation criterion of social legal and social non-legal norms - a criterion of the order of consideration.

It should be noted that the consideration of coercion as the main criterion for differentiation does not take into account its ambiguity. Since the assertion that the norm is legal and a violation of it activates a certain mechanism of coercion, which, in turn, ensures its implementation, then this assumes the recognition of the possibility of violation of the norm. The possibility of a violation becomes even more significant feature, than the possibility of coercion, because the latter does not always accompany the violation, and the challenge of an offender to the norm is the decisive moment in the mechanism of law. Law does not only presuppose the possibility to appeal, but the possibility organized in a certain way, that is, the institution of appeal. This institution has the definite form, namely the procedural, which ends with the decision. The process and result (a decision) are special phenomena, but although for law they are specific, they can be fully described exclusively by «the language of sociology». Therefore, we can agree with the American sociologist G. Kantorovic, who proposed to recognize them as a criterion of «social legal». In his work «Definition of Law»), he included a feature of «justiciability» in the definition of law. According to this feature, only those rules that allow decisionmaking are legal. In this case, justiciability is only the possibility of a decisionmaking (eventus judicii), but not a decision of its own [31, p. 32]. The latter actually means returning to the criterion of coercion, but the vector of analysis is directed not from the norm to the decision, but vice versa. Consequently, «the spirit of law» is filled with social content precisely because of the usage of «the language of sociology»

Conclusion. In modern science, it is impossible to maintain the «purity» of its own categorical apparatus. This impossibility often pushes scientists to radical actions: from unjustified scientific interpenetration to artificial separation. Both the first and second options can lead to a decline in science. That is why, today, when socio-humanities form and actively develop a common problem field, research is extreamly needed that, on the one hand, reveals a significant cognitive potential for such interdisciplinary interaction, and on the other hand, that allows us to invent ways of «self-preservation» for each science. And the relationship between Law and Sociology in this sense is very revealing. For sociologists, the difficulties associated with this are that the problems of law are fairly easily dissolved in the broader categories that are the subject of general Sociology. But yet E. Durkheim advised sociologists to study norms of law closely. He saw an objective indicator of social factors in them. But this advice was often forgotten by sociologists and, unfortunately, they continue to forget it. 


\section{REFERENCES}

1. Karbon'ye, Zh. (1986). Yuridicheskaya sotsiologiya. Moskva: Progress [in Russian].

2. Herasina, L. M., Pohribna, V. L. (2018). Yurydychna sotsiolohiya mizh pravom ta sotsiolohiyeyu: problemy rozmezhuvannya ob'yektno-predmetnoho polya. Science and society. Proceedings of the 5th International conference. Accent Graphics Communications \& Publishing. Hamilton, Canada. 348-370 [in Ukrainian].

3. Arnold, T. W. (1969). Law as Symbolism. In V. Aubert (Ed.). Sociology of Law. Selected readings (pp. 46-51). Baltimore: Penguin Books.

4. Hiddens, E. (1999). Pravova sotsiolohiya. Kiev: Osnova [in Ukrainian].

5. Gurvich, G. D. (2004). Sotsiologiya prava. Filosofiya i sotsiologiya prava. Izbrannyye sochineniya (pp. 565-780). Sankt-Peterburg: Izdatel'skiy Dom S.-Peterb. gos. un-ta [in Russian].

6. Erlikh, O. (2011). Osnovopolozheniye sotsiologii prava/per s nem. M V. Antonova. Sankt-Peterburg: Izdatel'skiy Dom SPbJU [in Russian].

7. Cardozo, B. (1947). Jurisprudence. Selected Writings of Berijamin Nathan Cardozo (pp. 7-46). New York: Matthew Bender.

8. Cardozo, B. (1924). The Grow th of the Law. New Haven, Konnektykut: Yale University Press.

9. Cardozo, B. N. (1921). The Nature of the Judicial Process. New Haven: Yale University Press.

10. Paund, R. (1999). Sotsial'noye upravleniye posredstvom prava. In Antologiya mirovoy mysli. V 5 t. T.3: Yevropa, Amerika XVII-XX vv. (pp. 678-680). Moskva: Mysl' [in Russian].

11. Paund, R. (1942). Social control through law. New Haven: Yale Univ. Press; Oxford Univ. Press.

12. Uorren, S., Brandeys, L. (2013). Pravo na pryvatnist'. Pravo SShA-US law, 1-2, 132-153 [in Ukrainian].

13. Frank, J. (1963). Law and the Modern Mind. Garden City, N. Y.: Doubleday\&Co.

14. Holmes, O. W. (1973). Law and the social factor. Justice Oliver Wendell Holmes. His book notices and uncollected letters and papers. New York: Da Capo Press.

15. Gumplovich, L. (2010). Osnovy sotsiologii. Moskva: Knizhnyy dom «Librokom» [in Russian].

16. Kistyakovskiy, B. A. (1990). Pravo kak sotsial'noye yavleniye. Sociologicheskie issledovanija - Sociological research, 3, 99-109 [in Russian].

17. Kistyakovskiy, B. A. (1998). Filosofiya i sotsiologiya prava. Sankt-Peterburg: Izd-vo Rus. Khristian. Gumanitarnogo in-ta [in Russian].

18. Kistyakovskiy, B. A. (1998). Ocherki po metodologii sotsial'nykh nauk i prava. In Anatomiya istorii. Istoriya russkoy pravovoy mysli. Moskva: Ostozh'ye [in Russian].

19. Korkunov, N. M. (2003). Lektsii po obshchey teorii prava. Sankt-Peterburg: Yuridicheskiy Tsentr Press [in Russian].

20. Petrazhitskiy, L. I. (2019). Teoriya prava i gosudarstva v svyazi s teoriyey nravstvennosti v 2 ch. Chast' 1. Moskva: Izdatel'stvo Yurayt [in Russian]. 
21. Petrazhitskiy, L. I. (2019). Teoriya prava i gosudarstva v svyazi s teoriyey nravstvennosti $v 2$ ch. Chast' 2. Moskva: Izdatel'stvo Yurayt [in Russian].

22. Bachinin, V. A. (2001). Nepravo (negativnoye pravo) kak kategoriya i sotsial'naya realiya. Gosudarstvo i pravo - State and law, 5, 14-20 [in Russian].

23. Dzhuzha, O. M. (Ed.). (2004). Sotsiolohiya prava: navch. posib. / O. M. Dzhuzha, I. H. Kyrychenko, V. S. Koval's'kyy ta in. Kiev: Yurinkom Inter [in Ukrainian].

24. Osypova, N. P. (Ed.). (2007). Sotsiolohiya prava: navch. posib. / V. D. Vodnik, YU.I. Zolotar'ova, H. P. Klimova ta in. Kharkiv: Pravo [in Ukrainian].

25. Savchuk, S. V. (2003). Yurydychna sotsiolohiya: predmet ta mistse v systemi yurydychnykh nauk: monohrafiya. Chernivtsi: Ruta [in Ukrainian].

26. Serdyuk, O. V. (2010). Sotsiolohichni aspekty metodolohiyi otsinyuvannya yakosti funktsionuvannya pravovykh instytutiv (na prykladi sudu). Visnyk Luhanskoho derzhavnoho universytetu vnutrishnikh sprav imeni E. O. Didorenka - The Bulletin of E. O. Didorenko Lugansk State University of Internal Affairs, 1, 32-40 [in Ukrainian].

27. Tammelo, I. (1978). Modern Logic in the Service of Law. Vien; New York: SpringerVerlag.

28. Rehbinder, M. (2009). Rechtssoziologie. München: Verlag C. H. Beck.

29. Kudryavtsev, V. N., Kazimirchuk, V. P. (1995). Sovremennaya sotsiologiya prava: uchebnik dlja jurid. fak. i in-tov. Moskva: Jurist [in Russian].

30. Yarmysh, O. N. (Ed.) (2005). Protyzakonne nasyl stvo v orhanakh vnutrishnikh sprav: Sotsiolohichnyy ta istoryko-pravovyy analiz / Kol. avt. Kharkiv: Vyd-vo Nats. Un-tu vnutr. sprav, Kharkivs'ka pravozachysna hrupa [in Ukrainian].

31. Kantorowicz, H. (1958). The Definition of Law / edited by A. H. Campbell. With an introduction by A. L. Goodhart. Cambridge [Eng.]: University Press.

Погрібна Вікторія Леонідівна, доктор соціологічних наук, професор, професор кафедри соціології та політології Національного юридичного університету імені Ярослава Мудрого, м. Харків, Україна

Сахань Олена Миколаӥвна, кандидат соціологічних наук, доцент, доцент кафедри соціології та політології Національного юридичного університету імені Ярослава Мудрого, м. Харків, Україна

\section{ПРОБЛЕМА ВИКОРИСТАННЯ «МОВИ СОЦІОЛОГЇ̈» В ЮРИДИЧНІЙ ТЕОРІЇ ТА ПРАКТИЦІ}

Постановка проблеми. Сучасний розвиток системи сочіогуманітарних наук характеризусться органічним переплетенням їхнього об 'сктно-предметного поля, категоріального апарату та методології й методів дослідження. В иьому сенсі сочіологія часто виконує роль «транслейтера». Ця роль найбільиою мірою реалізується при створенні, функиіонуванні та розвитку міждисциплінарних наукових 
напрямів, серед яких особливе місие посідає той, щзо виник на стику соціологій та юриспрудениіті. В статті пропонується аналіз особливостей використання мови сочіології в дослідженні правових явищ, в периу чергу, тих що формуються навколо ключового поняття - сочіальна норма.

Аналіз останніх досліджень та публікацій. Традиційно проблеми нормативного врегулювання соціальних відносин розглядаються юристами в рамках загальної теорії права. Особливо тут слід виділити роботи європейських та американських дослідників Т. Арнольда, Г Гурвіча, О. Ерліха, Б. Кардозо, Р. Паунда, С. Уоррена та Л. Брандейса, Дж. Френка, О. Холмса. Цікавими с роботи представників «скандинавської» иколи соиіологій права - А. Хегерстрема, В. Лундстедта, С. Пасса, В. Оберта, X Kлєтте, В. Гольдимідта, Т Еккгоффа та ін., а також вчених «італійськой» школи - А. Пагані, Г. Мартінотті, Е. Моріондо та ін. Серед вітчизняних науковців заслуговують уваги доробки Л. Гумпіловича, Б. Кістяківського, М Коркунова, Л. Петражицького, а також сучасних дослідників - В. Бачиніна, О. Джужси, Н. Осипової, С. Савчука, О. Сердюка.

Метою даної статті с аналіз можливостей використання «мови сочіологї̈» в правових дослідженнях.

Виклад основного матеріалу. Вихідною точкою такого аналізу запропоновано вважати той факт, що соиіологія досліджує правові феномени як різновид феноменів сочіальних. Дослідження виявило, що право слід розмежовувати як з системою, регульованою внутрішніми спонуками людини (особистісною мораллю), так i з апаратом зовнішнього спонукання, щио використовується суспільством. Останню категорію, яка не відноситься ані до права, ані до моралі, сочіологи запропонували називати нравами, розрізняючи серед них власне нрави, або звичай (англ. mores) і повсякденні звичайності (англ. - folkways). Це дозволило їм побудувати триланкову конструкиію, яка стала сьогодні класичною: право; звичаї; повсякденні звичайності.

Дія чієї об' $є$ днючої право і сочіологію конструкиії розглянута на прикладі аналізу співвідночення чілей та засобів їх досягнення при оцінці правових явищ та їхніх наслідків.

Висновки. В сучасній науці зберегти «чистоту» власного категоріального апарату неможливо. Ця неможливість часто підитовхус науковиів до радикальних дій: від невиправданого наукового взасмопроникнення до итучного відокремлення. I периий, і другий варіанти можуть призвести до занепаду науки. Тому съогодні, коли соиіогуманітарні науки формують і активно освоюють спільне проблемне поле, вкрай потрібні дослідження, які, з одного боку, розкривають значний пізнавальний потенціал такої міждисциплінарної взаємодії, а з іниого, дозволяють винайти способи «самозбереження» для кожної науки. I стосунки між правом і сочіологію в цьому сенсі є вельми показовими. Для сочіологів пов 'язані з иим труднощі полягають в тому, що проблеми права досить легко розчиняються в більи иироких категоріях, які входять до предмету загальної сочіології. Втім ще Е. Дюркгейм радив сочіологам уважно вивчати норми права. Він убачав в них об'сктивний індикатор сочіальних чинників. 
Ключові слова: мова сочіології, категорії сочіологіӥ в праві, сочіологія права, сочіальні правові норми, сочіальні неправові норми.

Погребная Виктория Леонидовна, доктор социологических наук, профессор, профессор кафедры социологии и политологии Национального юридического университета имени Ярослава Мудрого, г. Харьков, Украина

Сахань Елена Николаевна, кандидат социологических наук, доцент, доцент кафедры социологии и политологии Национального юридического университета имени Ярослава Мудрого, г. Харьков, Украина

\section{ПРОБЛЕМА ИСПОЛЬЗОВАНИЯ «ЯЗЫКА СОЦИОЛОГИИ» В ЮРИДИЧЕСКОЙ ТЕОРИИ И ПРАКТИКЕ}

В статье анализируется целесообразность и возможность использования «языка социологии» в юриспруденции. Доказывается, что «язык сочиологии» не только способствует реализации методологической функиии права, но и активно поддерживает «дух права» в исследовании сочиальных прочессов. Подчеркивается, что сосуществование в современном обществе двух систем норм-соџиальных правовых и соииальных неправовых - требует поиска разграничительных критериев. В качестве таких критериев предложено использовать критерий принуждения и критерий порядка рассмотрения.

Ключевые слова: язык сочиологии, категории сочиологии в праве, сочиология права, сочиальные правовые нормы, сочиальные неправовые нормыл.

\section{$\sin 8$}

